\title{
Methods and algorithms of ensuring of functional persistence of subsystem of information exchange in the system of airspace control
}

\author{
V.V. Kireienko ${ }^{1}$, O.V. Barabash ${ }^{1}$, I.P. Salanda ${ }^{2}$ \\ ${ }^{1}$ National Defence University of Ukraine named after Ivan Cherniakhovskyi, Kyiv, \\ ${ }^{2}$ Kremenets Oblast Humanitarian and Pedagogical Academy Taras Shevchenko, Kremenets \\ ${ }^{1}$ Corresponding author. E-mail: zrk77@ukr.net
}

Paper received 01.02.21; Accepted for publication 16.02.21.

\author{
https://doi.org/10.31174/SEND-NT2021-250IX31-08
}

\begin{abstract}
Absrtact. The article is dedicated to the structure of functionally persistent subsystem of information exchange (SIE) in the system of airspace control. Taking into account the character of hierarchical structure of the subsystem of information exchange the research was carried out with the help of graph model, namely the questions of best-connected structures were considered. Mathematical model of functionally persistent subsystem of information exchange is an unoriented graph with reliable vertices and unreliable edges. Optimal algorithm during the choice of topology of functionally persistent subsystem is offered. Given algorithm allows to get the estimation of functional persistence of system relatively expeditiously.
\end{abstract}

Keywords: functional persistence; subsystem of information exchange; unoriented graph, topology, algorithm.

Introduction. The research of existing scientifically justified approaches [1-3] to improving of the effectiveness of complicated technical systems, to which subsystems of data transferring belong entirely, allowed to make a conclusion about establishing in the last several years the new priority approach, connected with ensuring the characteristic of functional persistence in the system.

Under the functional persistence of the object should be understood its tendency to continue performing its functions during preset time in the limits, which are preset by regulatory requirements in conditions of counteraction and influence of malfunctions and failures [3]. The research showed that functional persistence of complicated technical subsystem combines the qualities of faultlessness, reliability and survivability. Functional persistence is ensured by the use in complicated technical system different existing types of indulgence (structural, informational, temporal, loading etc.) through redistribution of resources with the aim of eliminating the consequences of emergencies.

Related publications. Analysis of the works [4-7] was carried out in the area of projecting optimal topologies SEI and it revealed two classical approaches to the targetsetting:

- synthesis of the network on the criterion of the minimum of average time of delay in notice in the network with given limitations on reliability and cost;

- synthesis of the network on the criterion of the minimum of the cost with limitations on the indicators of reliability.

In [8] the use of structural indicators of reliability and coherence (degree of output arcs) were considered. At the same time, probabilistic characteristics of elements of the network - probability of the fault of network nods and channels of data transmission - were not taken into account. Lately heuristic algorithms are widely used for solving the tasks of optimization of networks of big size [9]. Complexity of their use is due to the adaptation of their parameters. Research in the sphere of structural reliability of systems [10], the quality of their functioning, analysis of the criteria of assessing findings, accounting plurality of really existing limitations for the tasks of big size almost unexistant.

The aim of the article is development and research of the methods and algorithms of analysis of functional persistence, as well as synthesis of optimal topologies of subsystem of information exchange with the aim of ensuring functional persistence.

Materials and methods. To reach the target will be used its graph representation as the most widespread and easy form of representing the structures in general. Let's say that the vertices of the graph are the nods of commutation, and the edges are communication lines. The methods of theory of graphs and theory of multitudes were used for research. The results of the work of the algorithms of structural coherence of subsystem on the indicator of probability of coherence, which allows to reveal vulnerabilities of the topology of subsystem, the reserving of which will allow to significantly increase the persistence of subsystem.

Analysis of the works [9-12] in the area of functional persistence and structural reliability allowed to define a lot of quantitive indicators of assessing structural reliability: minimum cut and probability of coherence. The multitude of methods of calculating the probability of coherence of subsystem of information exchange, like any other complicated subsystem, fall into two independent sub multitudes: precise and crude methods of calculation. Practical use of any method is defined by the task-setting, the level of precision of initial probabilities of operability of the elements of the system (subsystem). Some precise analytical methods are developed for definite structures of systems of data transmission. Precise methods of defining the probability of coherence considered in [3] can be used only for systems in which the number of nods of commutation is less than twenty. Under condition of increasing the number of nods this task becomes unfeasible on modern computer facilities. For practical realization of analysis and synthesis of functionally persistent subsystem of information exchange it is reasonable to use crude methods. So in the article while defining the probability of coherence crude methods are used.

Results and discussion. The structure of the subsystem of exchanging information is represented as an unoriented graph $G(V, E), \quad v_{i} \in V, e_{i j} \in E, \quad i, j=1, \ldots, N$, which is described by adjacency matrix $S$ 


$$
S=\left\|S_{i j}\right\|, \quad S_{i j}= \begin{cases}1, & \text { if } e_{i j} \in E ; \\ 0, & \text { if } e_{i j} \notin E .\end{cases}
$$

where $V$ - set of the vertices of the graph;

$E$ - set of the edges of the graph.

In the graph $G(V, E)$, the vertices of the graph $v_{i}$ are nods of commutation of SIE, and the edges of graph $e_{i j}-$ lines of connection

For SIE let`s say that the system should perform two main functions:

-processing, storing and retrieving of the necessary information;

- transmitting the information between the nods of commutation

Basing on above we can formulate the main requirement to functional persistence of SIE:

1. To ensure functionality of all nods of commutation (NC):

$$
\forall v_{i} \in V \Leftarrow \omega_{i}(\tau)=1, \quad \tau \in[0, t),
$$

where $V=\left\{v_{i}\right\}$ - a set of nods commutation SIE;

$\omega(\tau) \quad$ - Boolean function, which takes value 1 if the $\mathrm{NC}$ is functional and $0-$ otherwise;

$\tau, t$ - time of exploitation.

2. To ensure information transmission through main and reserve routes:

$$
\forall v_{i}, v_{j} \Leftarrow \exists v_{j} \in \Gamma_{i}, \quad i, j=1,2, \ldots, n,
$$

where $\Gamma_{i}$-a set of achievable vertexes of the graph from the vertice $v_{i}$;

$n$-number NC in the subsystem of processing the information.

According to above, the method of the search of minimum cut graph (Shtor-Wagner algorithm) is used to define the probability of coherence [13]. The work of the algorithm starts with giving the adjacency matrix of an undirected connected graph is given to the inputs of the algorithm. The result of the work of the algorithm is the global incision, that is to say the set of edges of the graph with minimal total weight, the removal (damage) of any edge divides the graph into two unrelated subgraphs. On each iteration we have two sets of graph $G$ : the set of vertices, which are included in some subset $A$ and the set of other vertices. With the help of the Shtok-Wagner algorithm it is possible to find the incision between them. Obtained incision is put into the set of local minimum incisions, from which the global minimum incision is chosen later.

At the beginning of the work of the algorithm in adjacency matrix $C$ graph $G$ all edges are given the weight $w_{e t}=1, t=1, \ldots, m$. Shtok-Wagner algorithm realizes $(n-1)$ iteration, and each of them is made of the following successive steps:

Block diagram of Shtok-Wagner algorithm is represented on fig. 1

Stage 1 . Enter an auxiliary set of vertices $A$, which is empty on the first stage: $A=\varnothing$

Stage 2. Add to set A one arbitrary vertice of graph $G$,

$$
\text { e.g. } i, i \in\{1, n\}: A=A \cup\{i\}
$$

Stage 3. Find the total weight of $W$ edges, which combine the vertices of the set $A$ with all other vertices of graph: $W=\sum_{i \in A} \sum_{j \notin A} w_{i j}$

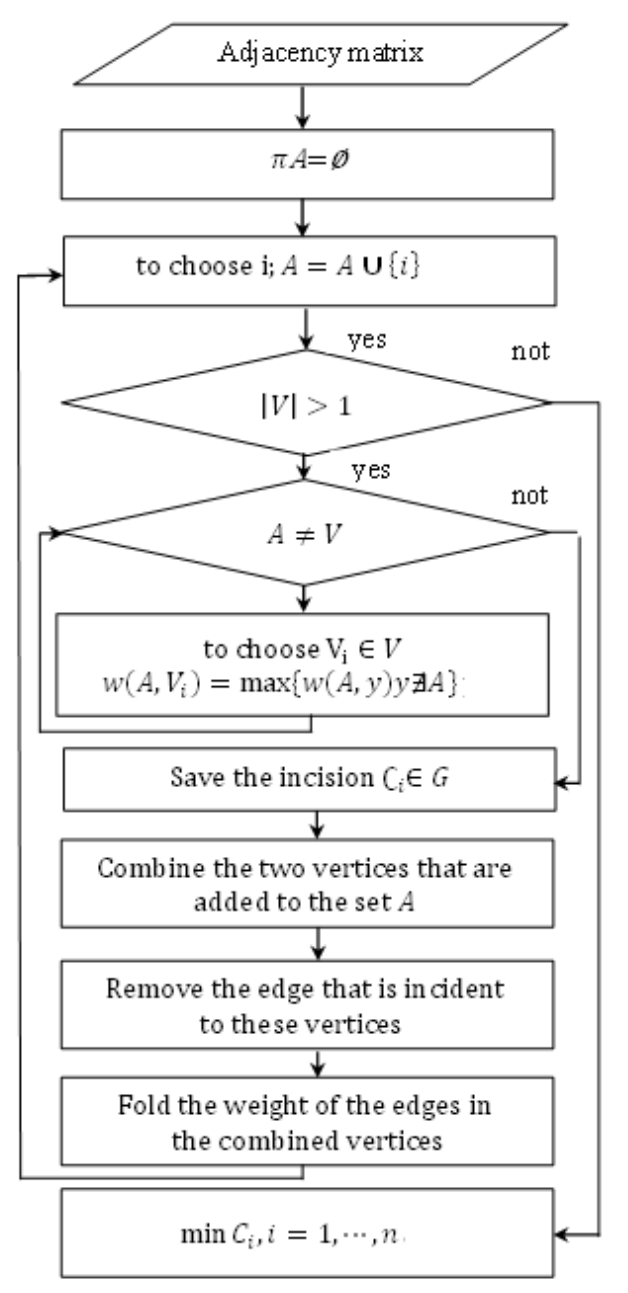

Fig. 1. Block diagram of the Shtor-Wagner algorithm

Stage 4. Find vertice $K$, which is not included in set $A$, and which has maximum total weight of the edges from it to the vertices, which are included into the set $A$, that is $\sum_{i \in A} w_{i k} .=\max _{j \neq A} \sum_{i \in A} w_{i j}$ Add vertice $\kappa$ to set $A$.

Stage 5. Repeat stages 3 and 4 until A is equal to set $V$ of the graph $G: A=V$

Stage 6. Combine two added vertices to set $A$ as the last and the second to last, to one. While this the edge incident with this vertices is removed and the weight of the edges appeared after merging the vertices is calculated. Put down the value of total weight of the edges (incision power) to the set of local reserves. Incision is memorized into some interjacent set $S$.

Stage 7. Repeat stages 2-6 until on the iteration (n-1) graph $G$ consists of one vertice.

Stage 8. Choose from the set of local minimal incisions $S$ the least incision, which will be the estimation of structural coherence of SIE.

So, while building up the structure of SIE it is possible to estimate different topologies of the structure by the 
lead indicator, which defines the set of minimum incisions of the graph-model SIE.

Proposed indicator of probability for estimating the functional persistence of SIE, which is defined by the minimum number of incisions of the graph-model with the lowest probability of fault, allows to localize the most vulnerable parts in the topology of network. Also it is necessary to mention that in need of estimating vulnerability of SIE in the process of its functioning if there are conditions of the faults of channels and their restoration, it is necessary to constantly monitor the conditions of networks for defining minimum incision of active configuration of the topology of the network and redistribution of download between channels.

Analysis of active configuration of network allows to predict critical conditions, when as a result of the influence of internal and external destabilizing factors on the channels of transmission there is a potential threat of the fault of all the network or its part. Practical realization of the algorithm of the search for critical parts in the network will allow to significantly improve functional persistence of the network.

\section{Conclusions.}

1. Using the minimum incision of the graph as the indicator of reliability while projecting the topology of subsystem of information processing in comparison with such indicator as minimum level of output arcs of the graph, generally allows to increase the functional persistence of the topology of the system. Increasing the value of minimum incision of the graph influences the increase in possible routs of delivery the information packs and consequently improves functional persistence of subsystem of data transmission and demotes probability of isolation of separate system nodes.

2. Identifying minimum incisions in subsystem of information processing of the system of airspace control allows to identify vulnerable places in the structure of the network. Apart from that, minimum incision corresponds to the area of the network with the lowest capacity.

3 . The results of the work of the algorithm of analysis of structural coherence of subsystem of information exchange by the indicator of probability of coherence, which allow to identify vulnerable places of the topology of the subsystem, are shown. Reservation of these places will allow to significantly increase functional persistence of the system of airspace control.

\section{REFERENCES}

1. Dodonov A.G. The survivability of information systems / A.G. Dodonov, D.V. Lundy - K .: Sciences. opinion, 2011. 256.

2. Mashkov O.A. Prymenenye teoryy funktsyonalno ustoichyvыkh system dlia reshenyia zadach navyhatsyy y uprav-lenyia obъektamy vyda «makrosystema»/O.A. Mashkov, O.A.Kononov// Systemy upravlinnia, navihatsii ta zviazku". - K.: TsNDI UiN, 2007. - Vyp 3, - S.15-19

3. Barabash O.V. Building functionally stable distributed information systems / O.V. Barabash. - K.: NAOU, 2004, 226.

4. Sobchuk V., Kapustian O. Approximate Homogenized Synthesis for Distributed Optimal Control Problem with Superposition Type Cost Functional. Statistics, Optimization and Information Computing, June 2018, Vol. 6, Issue 2. P. $233-239$

5. Musiienko A.P. Diahnostychna model bezdrotovoi sensornoi merezhi na osnovi vzaiemnykh perevirok elementiv merezhi / I.V. Pampukha, O.V. Barabash, A.P. Musiienko, M.O. Koval // Zbirnyk naukovykh prats Viiskovoho instytutu Kyivskoho natsionalnoho universytetu imeni Tarasa Shevchenka. - K.: VIKNU,2017. - Vyp. 57. - S. 160 - 168.

6. MashkovO.A. Prymenenye teoryy funktsyonalno ustoichyvыkh system dlia reshenyia zadach navyhatsyy y uprav-lenyia obъektamy vyda «makrosystema»/O.A. Mashkov, O.A.Kononov// Systemy upravlinnia , navihatsii ta zviazku". - K.: TsNDI UiN, 2007. - Vyp 3, - S.15-19.
7. Musienko A. Methods of self-diagnosis of telecommunication networks based on flexible structures of test connections / O. Barabash, N. Lukova-Chuiko, A. Musienko // Zborník príspevkov z medzinárodného vedeckého seminára «Riadenie bezpečnosti zložitých systémov». 23 - 27 februára 2015. Liptovský Mikuláš, Slovakia: Akadémia ozbrojených síl generála Milana Rastislava Štefánika, 2015. - Str. 226 - 231.

8. Kniazeva N. A. Alhorytmы otsenky strukturnoi zhyvuchesty ynfokommunykatsyonnoi sety / N. A. Kniazeva Suchasni informatsiino-komunikatsiini tekhnolohii. VIII nauk.- tekhn. konf.: zbirnyk tez. - K.: 2012. - S. 192-193.

9. William Stallings. Operating Systems - Internals and Design Principles, 7th Edition. Prentice Hall, 2011. 816 p. ISBN 013230998X

10. Shubinsky I.B. Structural reliability of information systems. Methods of analysis. Ulyanovsk: Regional Printing House Print Yard, 2012. 216

11. Mozhaeva I.A. Current trends in structural and logical analysis of the reliability and cybersecurity of ACMS / I.A. Mozhaeva, A.A. Nozik, A.V. Strukov http: // www. szma.com/mabr2_2015.pdf.

12. Zaichenko Yu.P. Structural optimization of computer networks / Yu. Zaichenko, Yu.V. Gonta - K .: Engineering, 1986. - 167

13. Stoer M., A simple min-cut algorithm / M. Stoer , F. Wagner // Jornal of the ACM. 1997.- Vol. 44, No. 4. Pp.- 585-591. 